Article

\title{
Seeing What's Right in Front of Us: The Bone Clocks, Climate Change, and Human Attention
}

\author{
Elizabeth Callaway \\ Environmental Humanities Program, The University of Utah, Salt Lake City, UT 84112, USA; \\ elizabeth.callaway@utah.edu
}

Received: 1 November 2017; Accepted: 18 January 2018; Published: 26 January 2018

\begin{abstract}
The scales on which climate change acts make it notoriously difficult to represent in artistic and cultural works. By modeling the encounter with climate as one characterized by distraction, David Mitchell's novel The Bone Clocks proposes that the difficulty in portraying climate change arises not from displaced effects and protracted timescales but a failure of attention. The book both describes and enacts the way more traditionally dramatic stories distract from climate connections right in front of our eyes, revealing, in the end, that the real story was climate all along.
\end{abstract}

Keywords: climate change; clifi; digital humanities; literature and the environment

Climate change is notoriously difficult to render in artistic and literary works. In the environmental humanities, there is an entire critical conversation around how and whether climate change can be represented in current cultural forms. The challenges often enumerated include the large time scales on which climate operates (Nixon 2011, p. 3), the displacement of climate effects (p. 2) literary plausibility of including extreme events in fiction (Ghosh 2016, p. 9), and the abstract nature of both the concept of climate (Taylor 2013, p. 1) and the idea of collective human action on the planetary scale (Chakrabarty 2009, p. 214). In this article, I argue that David Mitchell's novel The Bone Clocks proposes a different primary difficulty in representing climate change. It is not that climate change causes and effects are too slow or displaced to be felt with immediacy or that climate is too abstract. Rather, the novel indicates that climate effects are all around us all the time. Climate change is right there, available to our immediate experience. Similarly, the connections among industry, current lifestyles, and climate are readily observable. However, The Bone Clocks models the encounter with climate as characterized primarily by a failure of attention to those signals that are right in front of us. Over the course of the book climate is made present only to be immediately ignored in favor of the more conventional stories of interpersonal drama and the struggle between good and evil. The Bone Clocks is a fictional exploration of the discrepancy between the stories literature is proficient at telling and the stories it needs to take on in the face of climate change. Simultaneously, it is an example of the new type of story that our era of anthropogenic climate change demands.

Engagement in environmental themes is a characteristic of David Mitchell's work more broadly. By the end of Cloud Atlas, nearly the whole globe is uninhabitable, and in Ghostwritten, an artificial intelligence called "Zookeeper" is deciding humanity's fate given that, in its analysis, humanity is wrecking the planet through oil spills, attempted nuclear strikes, river contamination, sea level rise, and mass extinctions (Mitchell 2007, p. 419). Critics have read the environmental element in Mitchell's works as concerned with a "transhistorical predacity that drives human civilizations" (Shoop and Ryan 2015, p. 93). This predacity results in social injustice, raises questions about Enlightenment notions of progress ( $\mathrm{Ng} 2015, \mathrm{p}$. 107), and causes the environmental catastrophes through which humanity reaps the consequences of its own nature (Harris 2015b, p. 5). Scholars have noted that the expanded spatial and temporal scales at which Mitchell's narratives take place allow for this consideration of slow-moving environmental catastrophe that takes generations to play out 
(Harris 2015a, p. 149). For example, Ian Baucom argues that Cloud Atlas narrates the many entangled timescales of environmental damage-geological time, human species time, lifetimes, and organic time-resulting in the portrayal of humanity as an active force in natural history (Baucom 2015, p. 137). And while Cloud Atlas, Ghostwritten, and even Slade House take place across decades and around the globe, none of Mitchell's novels engages climate change so directly as does The Bone Clocks, which ends with a drastically changed climate. While much of Mitchell's oeuvre has been read as speaking to our current moment of environmental crisis, my focus will be on the narration of inattention to rather than the presence of readily observable environmental degradation.

As Min Hyong Song suggests, depiction (like Mitchell's) of increased connections among far-flung places and timescales might be incidental rather than integral to grappling with planetary environmental concerns. While Song is interested in how Karen Tei Yamashta's work represents a "planetary becoming" that evinces an interest in how environmental concerns increasingly underlie globalized social relations (Song 2011, p. 557), I am interested in how Mitchell depicts the inability to sustain concentration on this very connection between the ecological and the social that is Song's primary interest. While The Bone Clocks does present humanity as an active force in natural history, this is coupled with the inability to tell ourselves the kinds of stories that would be necessary to represent humanity as such.

The Bone Clocks begins prosaically in 1984 with a 15-year-old, working-class teen, Holly Sykes, who leaves her parent's house after a fight with her mother intent on living with her older boyfriend. Though Holly narrates only the first chapter and the final one (this time as a 74-year-old matriarch), her life will become one of the narrative threads that hold the novel together. The Bone Clocks consists of six relatively independent stories told in five voices across six decades. While the first and last chapters are narrated by Holly, the other four sections are told by a con-artist/Cambridge undergraduate (Hugo Lamb), an Iraq War journalist (Ed Brubeck), a failing novelist (Crispin Hershey), and a Canadian psychologist/immortal being (Iris Fenby/Marinus). The appearance of Holly in each of these character's lives as a love interest, spouse, friend, and an ally connects each piece into a loose whole. Holly is the connective tissue of the novel, and though the middle sections are primarily concerned each narrator's own travails rather than Holly, we see snapshots of her life through various perspectives across the decades. In addition to Holly, the stories are held together by the intermittent eruption of a fantasy subplot (or uberplot) into each section. This fantasy plot both ties together and interrupts the narratives in each chapter, injecting what is otherwise a story about family life, marriage strain, career choices, midlife crises, and teenage angst with epic stakes. The characters each get embroiled in one way or another in an "invisible" war that is taking place between two groups of immortal characters. One group, the "Atemporals" are benevolent and are simply reborn into recently vacated bodies upon their death (with consciousness and memories intact). The other group, the "Anchorites" (who are also referred to as "carnivores"), steals immortality by murdering psychically inclined innocents in an arcane ceremony that allows them to ingest souls and thereby halt the aging process.

If this summary of a book that is both about the intricacies of everyday family life and an eternal battle between immortal beings seems fraught in terms of genre, it is because this is the case. Even for an author known for pastiche, parody, and juxtaposition, The Bone Clocks is generically surprising. Cloud Atlas, after all is composed of six stories all of different genres (19th-century travel writing, epistolary novel, detective fiction, social farce, dystopia, and post-apocalyptic science fiction). But in Cloud Atlas, these genres stay relatively confined to their story; they don't erupt into the middle of what is otherwise literary fiction or "'serious' realism," as Joseph Metz designates it in his perceptive article on genre in The Bone Clocks. I follow Metz in reading the novel as characterized by "the permeation of these most recognizably mimetic aspects of the text by "supernatural" elements" (Metz 2017, p. 122). What Metz calls "supernatural elements" and "pulp mayhem," I instead follow the novel in calling "fantasy." In moments of sometimes hilarious self-reference, the novel often slyly refers to its more imaginative elements as "fantasy" in particular. In one instance, fictional novelist Crispin Hershey 
encounters a particularly harsh review of his (supposed) comeback book in which the critic writes, "The fantasy subplot clashes so violently with the book's State of the World pretensions, I cannot bear to look." Similarly, when Hugo Lamb contemplates how to interpret a series of strange events that befall him due to his recruitment into the ranks of the Anchorites, he labels his experiences "Plausible, if you live in a fantasy novel" (Mitchell 2014, p. 148). Although the bounds around and divisions within speculative fiction will always be fiercely contested, I agree with the novel's description of its supernatural elements as "fantasy" rather than science fiction. ${ }^{1}$ However, for my central thesis that The Bone Clocks models the relationship to climate as one characterized by distraction, the choice of "realism" and "fantasy" as the two genres is somewhat arbitrary. The effects of climate change surround the characters, but they are distracted by a better story (as is the reader). The interrupting genre of the distraction could be fantasy, pulp science fiction, romance, mystery, or any number of other types of story. What will be important for my analysis is that this plot distracts characters from climate because it is dramatic, has clear emotional stakes, and has a straightforward course of action that the characters should pursue to achieve success. Most importantly, success in this plot can be brought about by heroic individual agency.

Jesse Oak Taylor's conceptual rubric of the novel as a climate model provides a useful framework for understanding Mitchell's depiction of the repeated failure to represent climate. In Taylor's terms, novels can "perform the experience of the climatic encounter" (Taylor 2013, p. 3); they model the human engagement with climate. But unlike Taylor's exploration of Dickens' Bleak House, in which the London fog and other smoky and contaminated air mediates the encounter with climate, The Bone Clocks models the climatic encounter as a contact point that is about representation (or lack thereof). The primary characteristic of the interaction with climate is one of failing to represent, of climate fading to the background in favor of a focus on more easily understandable stories. This pattern recurs in the novel at all scales, from single sentences to the entire narrative arc of the novel. Climate and extreme weather events are plainly present, and while the characters perceive these phenomena, they are unable to represent them to themselves as important, make connections, detect patterns over time, or even focus their attention on climate for long.

In many ways, the problem of modeling climate in The Bone Clocks speaks to the challenges faced when atmospheric scientists model climate to, for example, tease out global temperature patterns. The climate encounter in The Bone Clocks can be viewed similarly as a problem of filtering signal from noise. One of the interventions the book makes is to depict climate as something available for the characters if they only had the ability to read it. Instead of being an inexperienceable abstraction, climate is all too real, just overlooked as an important narrative in the noise of more spectacular stories. The difficulty comes from the fact that climate is not the only local signal but merely one aspect of an overwhelming richness of information that is all right in front of the characters (and the reader). Like global temperature trends, The Bone Clocks contains an abundance of local noise that has to be filtered out in order to connect only the meaningful local signals into a global trend.

Inspired by the suggestion that reading climate might entail filtering local noise to detect large-scale patterns, as well as the multiple scales on which The Bone Clocks models the inattention to climate, my own reading of the climate of the novel will toggle between scales. I will use both small-scale, in depth analysis of sentences as well as graphs derived using text mining techniques that track the relative frequency of climate words across the entire narrative arc. But neither these displayed graphs nor the final close-readings comprise my modeling of the text. My sense of my own modelling of The Bone Clocks as well as The Bone Clocks' modelling of climate is aligned with Willard McCarty's description of modelling as "the continual process of coming to know by manipulating

1 Going by one of the most widely cited and long-lasting definitions of science fiction, Darko Suvin's "cognitive estrangement," the psychic communication and telekinetic battles of The Bone Clocks rely more on estrangement than cognition, marking the novel as fantasy. These powers do not rely on any advancement in technology; there is no "novum" in The Bone Clocks (Suvin 1972, p. 373). 
things, not an achievement, but an approximating convergence" (McCarty 2005, p. 28). Modeling is more process than end result, and it is in the activity moving between different formulations of the text and the climate within it that I hope to achieve a deeper understanding of the connections between story and climate. My own performative reading experiments with reading the textual representation of climate the same way the text suggests we represent the real climate encounter to ourselves: as paying attention to what is right in front of us by manipulating it in various ways to produce meaning, perhaps filtering out local drama to uncover the meaningful local signal that can be used to construct a global pattern.

The opening sentence of the book depicts the encounter with climate as an interaction that is more commonly characterized by distraction than modelling. Fifteen-year-old Holly Sykes begins the first chapter by looking out her window: "I fling open my bedroom curtains, and there's the thirsty sky and the wide river full of ships and boats and stuff, but I'm already thinking of Vinny's chocolaty eyes" (Mitchell 2014, p. 3). The "thirsty sky" in Holly's eye line is the first reference to the hot, dry weather that will characterize this section of the text, and the ships and boats visible from her window in industrial Gravesend, England, signal the global shipping industry. But by the time Holly can describe what is right in front of her (climate and industry), her thoughts are already wandering to a new, more attention-grabbing object: her boyfriend and his chocolaty eyes. She perceives climate but fails to register it in any meaningful way, instead moving on to literally and metaphorically "sexier" topics.

The entire first chapter, meaningfully titled "A Hot Spell," establishes climate as important only to draw attention away from it again and again. Even though the whole section is characterized by heat and thirst, Holly cannot connect the anomalous weather to climate. She spends the section outdoors, exposed to the unseasonable weather but is distracted by the drama of her teenage life. It is June 1984, and Holly, after running away from home, spends a few days walking from Gravesend, England, to the Isle of Sheppy. She is ill-prepared for this foot journey and spends the entire time hot and dehydrated, comparing her tongue to "that oasis stuff they use for flower arranging" (Mitchell 2014, p. 23) and noting that her "whole head's parched" and her "mouth feels like a dying rat crapped in it" (p. 28). Compounding her lack of water is the anomalous hot spell. She notes that "the sun's got a punch to it" (p. 26), at one point comparing it to laser beams (p. 42). The repeated emphasis on the early summer heat and its resulting thirst cultivates the feeling that this heat is not normal or natural but atypical. And in fact, this heat is not natural. When Holly remarks that "the hot spell looks set to last" (p. 17), she is merely talking about the summer heat, but her words also apply to the long-term, real-world global temperature trends of climate change. It is worth noting that the action of this section occurs in 1984, the last summer in which the Earth exhibited below average global temperature. Less than one year later, February 1985, would be the last month in which global monthly temperature was ever again below average (Biello 2010). The first chapter of The Bone Clocks takes place right as the effects of greenhouse gasses first started manifesting as consistently higher global average temperatures. The "hot spell" that Holly refers to in the last days of June 1984, then, actually looks set to last for centuries.

The initial chapter of the book does more than just depict anomalous heat. From its very beginning, the novel establishes the co-presence of abnormal climate conditions and the petroculture industry, both of which loom in the background of Holly's journey across the landscape of England. Yet Holly fails to register either, in part because of the personal melodrama in which she is embroiled. During her entire journey through Gravesend, she is surrounded by signs of industry: "a cement truck trundles by and its fumy gust makes the conker tree way a bit and rustle. Breathe in warm tarmac, fried spuds, and week-old rubbish" (Mitchell 2014, p. 9). ${ }^{2}$ This description gestures to the cement industry, one of

2 Here, I read the cement truck and the smell of tarmac as particular manifestations of global oil infrastructure. The fried potatoes and garbage are unrelated, bonus odors that Holly breathes in along with the emissions of petroculture. The kind of reading I perform on The Bone Clocks, where a cement truck signals the cement industry and tarmac is connected to the bitumen of which it is made, is aligned with the types of surface readings that Stephen Best and Sharon Marcus explore in their special issue in Representations on Surface Reading (Best and Marcus 2009). 
the most carbon-intensive single industries, the presence of which is emphasized even further when Holly walks by the Blue Circle cement factory. "The wind unravels clouds from the chimneys of the Blue Circle Factory, like streams of hankies out of a conjurer's pocket. To my right, the A2 roars away over the marshes" (p. 20). This simile hints at an underlying unease about the way that the trappings of modernity seem to appear out of nowhere, easily, and without cost. These smokestacks are the conjurer's sleeve out of which petroculture infrastructures, like the A2, appear like magic. But just as the "clouds" from the smokestacks dissipate into thin air, so too does Holly's awareness of them fade as she moves onward in her journey and continues to brood about her cheating ex-boyfriend. Three times during her trip Holly finds herself passing the Grain Power Station, which, "provides electricity for Gravesend and half of Southeast London" (p. 32), a major part of the energy infrastructure in the area. During one of these appearances, she watches the lights at the oil-burning power plant blink on as the sun sets, establishing the Grain Power Station as a point that connects both sides of energy production and consumption in a single moment. And yet, Holly only ever sees industry momentarily before she is re-embroiled in her tumultuous emotions, and she never sees it as connected the climate conditions that oppress her movement. She can only see her personal drama: her boyfriend dumping her for her best friend and her unsympathetic mother.

Over the arc of the chapter, it not merely personal drama but a fantasy subplot that draws attention away from both climate and industry, a fantasy subplot that is tantalizingly intriguing, contains clear villains, and has relatively simple moral choices. The first appearance of the fantasy plot interrupts Holly's memories of another drought, this one from her childhood. She recalls:

I was seven years old in 1976. It didn't rain all summer and the gardens turned brown, and I remember queuing with buckets down the end of Queen Street with Brendan and Mam for water from standpipes, the drought got that bad. My daymares started that summer. I heard voices in my head." (Mitchell 2014, p. 16)

Although these unusual weather conditions occupy a prominent part of Holly's memory, they soon fade into the background of her recollection as the tale of what Holly calls "weird shit" (Mitchell 2014, p. 16) gains momentum. These voices are followed by manifestations of a special "friend," Ms. Constantin, who chats with Holly at night and whom no one else can see. One night, Ms. Constantin offers to help Holly with a school bully, and the older girl is hit by a car the next morning. The drama and intrigue surrounding these paranormal phenomena direct attention away from the weather and toward the mysterious nature of these events. The strangeness of this fantasy plot masks the fact that the weather is actually some pretty "weird shit" as well—weird shit that will eventually yield more widespread and devastating consequences in the novel.

By the time Holly arrives in Sheepshead, the paranormal plot has caught up with her again. She has fought a man with telekinetic powers, become a host to the soul of a benevolent immortal being, and had her memories of these events erased. As the action of the fantasy plot accelerates, the striking presence of anomalous weather falls away. The climate that at the beginning is immediately present to the senses fades to the background. This impression of the declining presence of climate in the story is reflected by the trends in the relative frequency of words associated with weather and industry as well as words associated with the fantasy subplot (see Figure 1).

The overall appearance and disappearance of climate over the entire length of The Bone Clocks models the same pattern established in the first chapter. On the book-length scale, the novel early establishes climate as important by featuring extreme weather prominently in the first two sections. "A Hot Spell" is followed in the next section by an extreme snowstorm event in the Swiss Alps. This striking presence of climate soon disappears, however, overlooked in favor the fantasy subplot. While weather is still present after Chapter 2's whiteout, it is less striking, extreme, and insistent on attention. Brighton Pier is sunny, and Toronto is rainy, but the presence of climate extremes is muted in the middle chapters (see Figure 2). Over the course of the novel, climate is pushed to the background and becomes mere filler endowing the novel's more sensational plot with texture, specificity, and what Roland Barthes calls "the reality effect" (Barthes 1987, p. 141), signaling nothing outside its own existence. 
Frequency of Weather, Industry, and Fantasy Words Across the Three Sections in the First Chapter

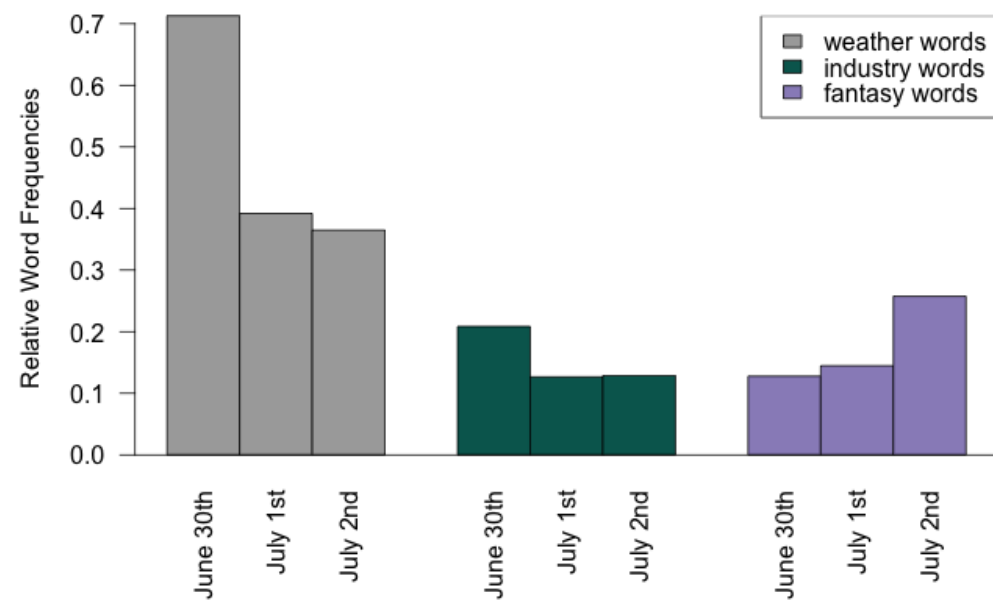

Figure 1. The presence of weather words, industry words, and fantasy words across the three sections of the first chapter (June 30th, July 1st, and July 2nd). The structure of the entire chapter mirrors the structure of the excerpts I have looked at in detail. Weather and industry words occur more frequently in the first section of the chapter than in later sections, while fantasy words figure more and more prominently as weather and industry word frequencies taper off. Climate and its causes are initially made present only to be superseded by a fantasy plot. For the words counted in each figure, see Appendix A.

As the arresting climate events of the first two chapters recede, the invisible war between the "Atemporals," and the "Anchorites" is slowly revealed. The Anchorites recruit Hugo Lamb in the second section, Holly's psychic powers help her husband, Ed Brubreck find their missing child in the third section, and Crispin Hershey finds himself interrogated by the Anchorites and used by those who want to make the hidden war public in the fourth section. These strange intrusions are only fully explained in the fifth section of the novel, which is narrated by an incarnation of an Atemporal. Iris Fenby is also Marinus, an Atemporal whose memories stretch back centuries. Holly, Marinus, and a group of other Atemporals engage the enemy in a final battle that takes place inside the sanctuary of the Anchorites.

The sleight of hand in which weather seems to recede to the background, to frame and surround the story rather than be the story, culminates in final battle of the penultimate chapter of the novel. Here, the characters encounter a fantastical place where weather does not exist at all. In order to fight the "Anchorite" carnivores, Holly and a host of Atemporals have to find and destroy the "Chapel of the Dusk," a structure that "decants" souls so that the Anchorites can consume them and maintain their immortality. As a building that stands outside of the fabric of reality, this chapel has no weather at all. After summoning the "Aperture," Holly and the Atemporals step through and find themselves on the staircase that leads to the Chapel. Holly notes the strange absence of everything in the atmosphere of the place: "The air here is not fresh or stale or warm or cool, though it carries the tang of bad memories" (Mitchell 2014, p. 519). This place of no weather is the setting for the climax of the fantasy plot-a breathtaking and bone-shaking battle between the Atemporals and the Carnivores. Just when all seems lost, the oldest of the Atemporals sacrifices her life in order to blow the chapel apart at its seam. As the Dusk slowly fills the chapel, obliterating everything it touches, Holly finds a series of tunnels in a familiar shape that leads her to safety back in her own time and place. In the end, the Anchorites are defeated, the Chapel is destroyed, and Holly survives. Good triumphs over evil, and the world is rid of the menace of immortal soul-thieves. 

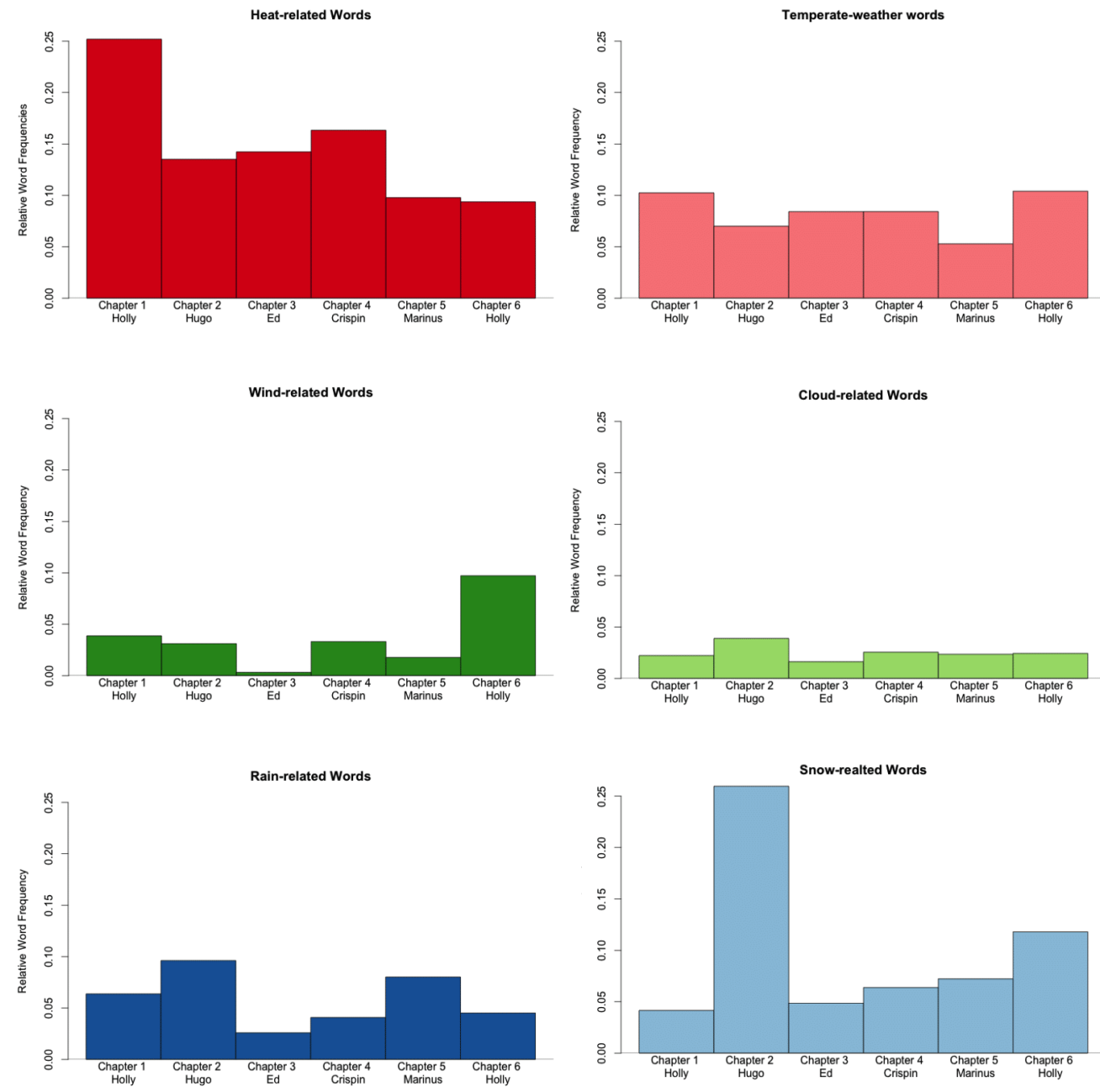

Figure 2. A comparison of the relative frequency of words associated with different types of weather across the six chapters in The Bone Clocks. The first and last graphs show that Chapter 1 is the hottest chapter, while Chapter 2 is the snowiest chapter respectively. The third graph shows that wind will make an appearance in the final chapter. While weather is present throughout the novel, heat and snow comprise the most extreme weather events. The temperate weather, clouds, and rain are less memorable. The final chapter turns wind into another example of extreme weather due to possible windborne radiation.

However, the world still ends. In the final chapter, the spectacle-filled plot is revealed as the real background: a mere distraction from the true threat. It turns out that the central threat even to Holly's own life was not carnivores but carbon. While the fantasy plot culminates in the second to last chapter, the final chapter describes years of climate extremes that remake the world more completely than any psychic battle. Figures 3 and 4 are a visual way to represent the global structure of the novel with the height of the fantastical distraction from climate followed by climate's reemergence in the final chapter. The characters' success in the fantastical plot does not matter in the final context of a larger world being torn slowly apart by climate change. The concluding chapter reveals that The Bone Clocks has been about climate all along. While critic Paul Harris sees the final section of the novel as "a kind of dangling dénouement detour into themes and places from previous books" (Harris 2015a, p. 153), I contend that it is the key to understanding the rest of the novel. It pulls the rug out from under the previous plot, exposing it as misdirection. The Bone Clocks is not about psychic battles and telekinesis. Rather, the novel is about the inadequacy of exactly that type of quick-moving, action-packed, unambiguous story despite its power to grab attention away from the more vital story of climate. 
The final chapter, set 20 years after the last battle in the invisible war, is once again from the perspective of Holly Sykes, now an 74-year-old grandmother living prosaically through the gradual "Endarkenment" and trying to care for her grandchildren as communication technologies go dark, electricity shuts off, and "every temporary shortage would turn out to be permanent" (Mitchell 2014, p. 563). While the Atemporals were fighting soul-sucking carnivores, climate change was slowly bringing an end to the world Holly knows.

\section{Relative Frequency of Extreme Weather Words}

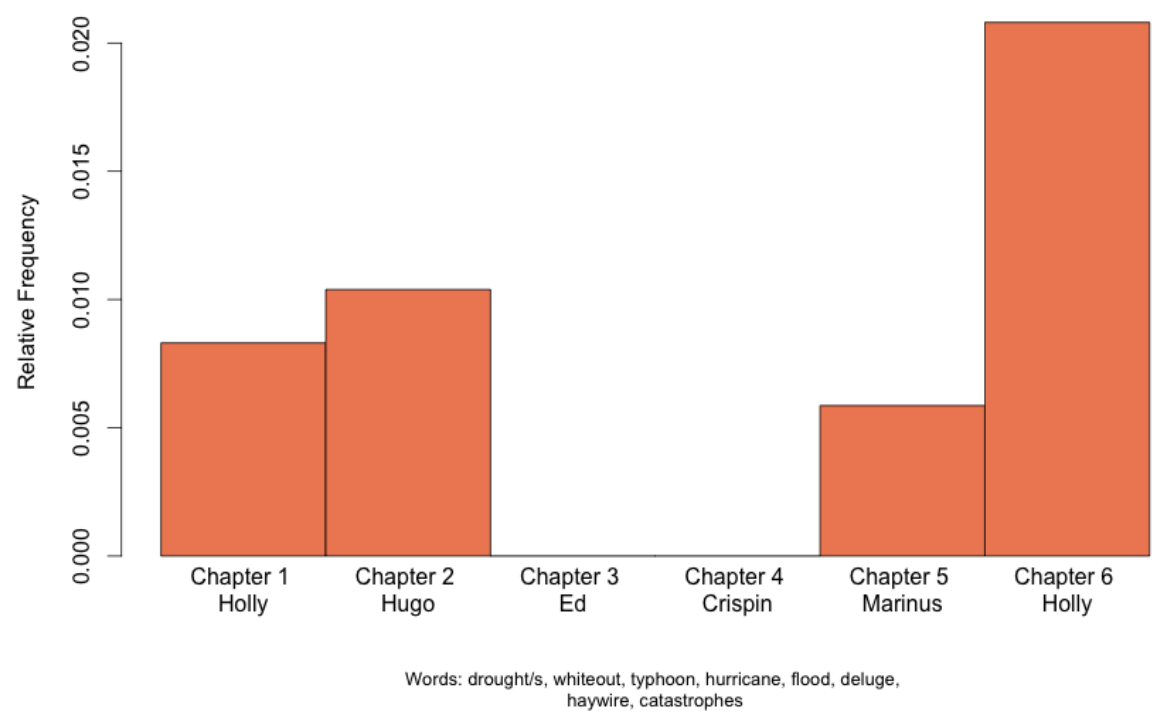

Figure 3. The relative frequency of extreme weather words in the text. Extreme weather features in the first two chapters, then is absent from the middle of the book, has a slight presence in the penultimate chapter, and comes back aggressively in the sixth and final chapter, which reveals that weather is what we should have been paying attention to throughout.

Relative Frequency of Fantasy Words Across Chapter

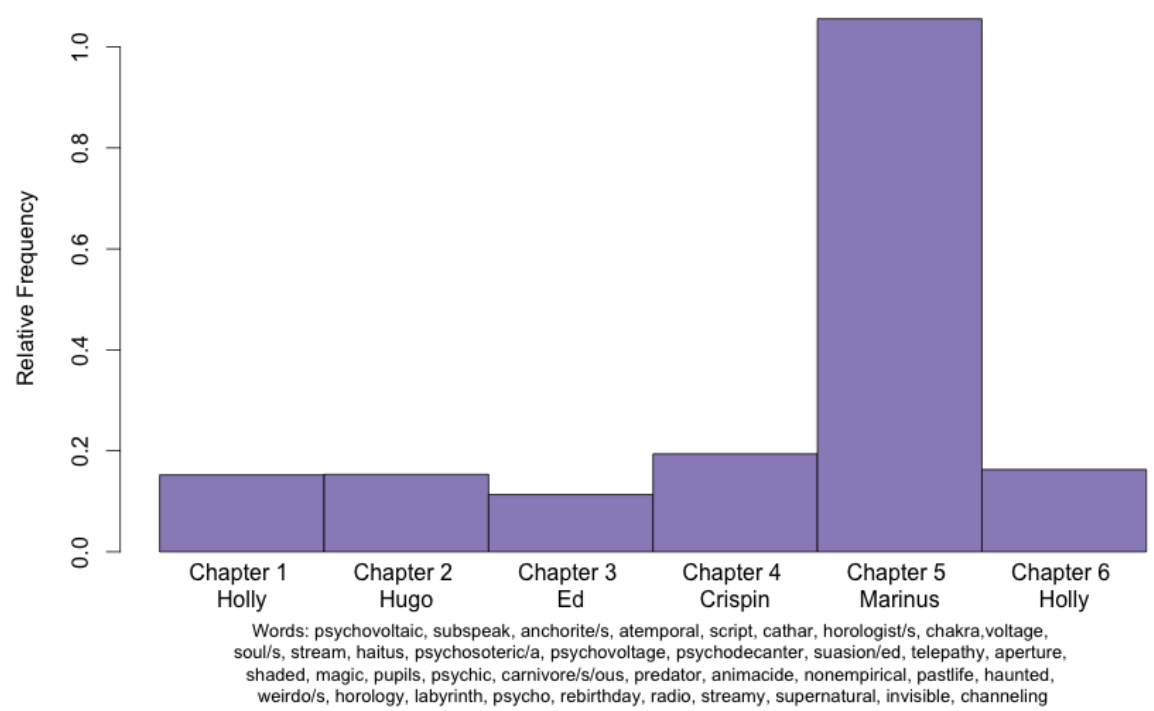

Figure 4. The relative frequency of words associated with the fantasy subplot. The fantasy slowly builds in each of the chapters until the penultimate one then drops off again suddenly in the final chapter when climate makes its comeback. 
Even from Holly's relatively privileged perspective in rural Ireland, it is evident that she is now living in an era defined overwhelmingly by absence. There is no oil, no gas, no central electricity, no motorized transportation outside of a few military and militia vehicles. Her world lacks reliable weather, political stability, regular means of sustenance, and safety. Her community is under constant threat from nuclear meltdown and roving militia. The loss that Holly feels for her loved ones and the world is sometimes overwhelming:

I take a deep, shuddery breath to stop myself crying. It's not just that I can't hold Aoife again, it's everything: It's grief for the regions we deadlanded, the ice caps we melted, the Gulf Stream we redirected, the rivers we drained, the coasts we flooded, the lakes we choked with crap, the seas we killed, the species we drove to extinction, the pollinators we wiped out, the oil we squandered, the drugs we rendered impotent, the comforting liars we voted into office—all so we didn't have to change our cozy lifestyles. (Mitchell 2014, p. 560)

It is clear that climate change, in this narrative, has already reached several devastating tipping points. Floods, extinctions, droughts, and deadlanding don't so much follow these tipping points as happen simultaneously in an intricate mesh of slow-moving environmental disasters. Holly's apocalypse, however, is not dramatic in the way we expect apocalypse to be. Rather, it is quotidian and prosaic. The apocalypse in The Bone Clocks, like the ones described in other novels about climate futures, is concerned with "present dwelling inside, rather than fearful anticipation of a potent new intimacy between people and their worlds" (Buell 2014, p. 265). It exists in the everyday: in Holly reaching for a tissue to dry her tears only to remember that the world is not a place that has tissues anymore. It is in her encouraging her grandchildren to pick the last of the blackberries because their ration boxes no longer include vitamins, and she's worried their diets aren't varied enough. It is her daily task of emptying the latrine bucket into the sea. It is in her inability to get a call through to her brother in England and the absence of pictures of dead loved-ones because she never bothered to print them out when she had things like a computer and a printer. By the time this chapter takes place, the arresting and spectacle-filled images of climate change are all over. There is no ability to share or access images of disasters anymore. "Footage of catastrophes flowed so thick and fast through the thirties that it was hard to keep track of which coastal region had been devastated this week, or which city had been decimated by Ebola or Ratflu" (Mitchell 2014, p. 562). But by 2043 in Sheepshead, Ireland, the apocalypse is not spectacular at all; it is slow, gradual, and completely devastating.

It is also an apocalypse in which the weather can no longer be ignored. In addition to the ever-present awareness of the role of climate change in bringing about all of the manifestations of the Endarkment that the characters feel-the loss of electricity, travel, communication, nourishment-weather trends are also constantly at the forefront of Holly's attention. In this way, the apocalypse functions in terms of its literal definition, as a disclosure, as what Wayne Meeks sees as a revelation "of a form of knowledge not accessible to the ordinary ways of knowing" (Meeks 2000, p. 462). Holly, far from being distracted from weather is now constantly attuned to it. She has developed the capacity to encounter climate and represent it to herself, to make connections between decades of weather, lifestyle choices, industry, and health. Her new capacity to represent climate trends to herself is evident when she mulls over the consequences of her generation's unwillingness to change its lifestyle: "In the early 2030s the seasons went badly haywire, with summer frosts and droughts in winter, but for the last five years we've had long, thirsty summers, long, squally winters, with springs and autumns hurrying by in between" (Mitchell 2014, p. 562).

Even more important than Holly's ability to experience average climate over time and represent those changes to herself is her attunement to the current weather right in front of her, especially that most invisible and ephemeral manifestation of weather: the wind. In 2043, the nuclear power station at Hinkley Point in England has failed, and Holly is monitoring a situation that is quickly unraveling. However, there is no reliable news about how deteriorated the containment is or how much nuclear contamination is spreading. Consequently, Holly is constantly checking from which direction the wind 
is blowing. One morning, she looks out her window and describes her thoughts as she gazes upon the scene below.

The sea holly and myrtle at the end of the garden are being buffeted: back they bend towards the cottage, then spring up, then bend back towards the cottage. This means something. Something I'm missing, even though it's there in front of me, as plain as day.

It's an east wind, blowing from England; from Hinkley Point. (Mitchell 2014, p. 587)

Even though she is not quite sure at first what the connection is among the weather she sees, industry, and health, she does not let her attention wander. This time, she is able to see what's right in front of her, "plain as day." Wind and weather make an undeniable reappearance in this last chapter, as does the presence of petroculture and broader energy infrastructure in the form of this foreboding nuclear power plant. In the end, the connection between climate, carbon, and the energy industry more broadly comes back with a force that cannot be denied. Weather, not fantasy, has been the story in The Bone Clocks; we were just too distracted to see it.

The final chapter makes the argument that the immortal Atemporals might have better invested their time in trying to push through climate policy, carbon taxes, or clean energy subsidies rather than fight serial killers who ritually kill four people each year. Literary critics have traditionally read the reincarnation of Atemporals and others in Mitchell's work as a way to expand the temporal scope of his novels, since Atemporals are potentially immortal, and the oldest member is as old as human civilization itself, with memories stretching back over 7000 years. Paul Harris, for example, argues that "The Atemporals provide a form of Anthropocene memory" (Harris 2015a, p. 152). However, in The Bone Clocks, what is most apparent about the Atemporals is, counterintuitively, their failure to take the long view. They are the characters who should be able to connect the human and the geological scales. They do not have to think hypothetically about climate in the context of the future of their grandchildren but rather can comprehend climate change as something that will directly affect the world they will live in for centuries and millennia to come. But they do not focus on climate. Like the other characters, the Atemporals are distracted from a potential recognition of climate as the story by an easier story. In the fantasy plot, there are identifiable villains to be defeated and a clear course of action. These immortal beings still invest in the story with heroes and a single, permanent (if sacrifice-filled) solution, while they could have been paying attention to the much trickier problem of climate.

My reading of the misreading of climate in The Bone Clocks suggests that lack of attention to climate is not a question of timescales so much as a question of story. The novel comments on the distance between the kinds of stories literature is good at telling and the kinds of stories we need to tell in the face of climate change. The Bone Clocks suggests that we don't necessarily need stories that take place over 7000 years, just ones that connect climate and culture. After all, the reasoning in the previous paragraph about climate's personal stakes for the Atemporals turns out to be true for Holly as well. It is not only her hypothetical great-grandchildren who experience the consequences of climate change, but she herself. She can see the devastation it has wrought within the timescale of her own lifetime. She is fully capable of experiencing the abstraction that is climate, of piecing together her experiences of weather over time, and of noting the connections between industry, policy, climate, security, and health. In The Bone Clocks, climate is presented as that which is right there in front of us if only we could filter out the noise of louder, more fantastic stories. However, the threat of climate change does not fit the template of stories that the characters find compelling, the kind of stories with which this novel baits its readers. This type of story-bait is exemplified in the narrative when an Atemporal muses on her way to the final showdown: "New York is damp, in a hurry, and indifferent to the fact that we Horlogists plus Holly are risking our metalives and life for total strangers, their psychovoltaic children, and for the unborn whose parents have not yet met" (Mitchell 2014, p. 507). This is indeed a compelling story. The narrative that readers follow through the book expertly draws attention away from things as mundane as damp weather in favor of subjects more heroic. Here is a story of humble champions risking their lives for people they will never know. However, the kinds 
of stories demanded by a changing climate may not be about risking lives in a spectacular battle but about dedicating lives to unclear paths of gradual recovery. Ours is a story about giving up "cozy lifestyles" (p. 560) rather than defeating evil. Climate change is a problem that certainly will take lives, but it also demands sustained attention to reading the connections that are already right in front of us.

Acknowledgments: Roberta Wolfson read and greatly improved an early draft of this article. The author is grateful for support from the Environmental Humanities Program at the University of Utah. Finally, the author would like to thank the anonymous reviewers at Humanities whose thoughtful suggestions, modifications, and insights benefited this article.

Conflicts of Interest: The author declares no conflict of interest.

\section{Appendix A}

Weather words: all words under the following categories: heat words, snow words, rain words, wind words, temperate words, and cloud words.

Industry Words: gas/oline, car/s, airplane/s, motor/s, diesel, factory/s, electricity, generator/tion, jet/s/ted, coal, mine/r/ing, industry/s/ial, oil, lights, mill/s, cement, asphault, fume/s/ing, combustion, carbon, pollute/d/tion, effluence, gravel, freighter, conveyor.

Fantasy Words: psychovoltaic, subspeak, anchorite/s, atemporal, script, cathar, horologist/s, chakra, voltage, soul/s, stream, haitus, psychosoteric/a, psychovoltage, psychodecanter, suasion/ed, telepathy, aperture, shaded, magic, pupils, psychic, carnivore/s/ous, predator, animacide, nonempirical, pastlife, haunted, weirdo/s, horology, labyrinth, psycho, rebirthday, streamy, supernatural, invisible, channeling.

Heat words: heat, hot, thirst/y, drought, dry, spell, sticky, glare/ing, bright/ness, dusty, oven, stewy, torching, flaming, parched, sweat/y/ing, laser, beams, sunglasses, melt/s, flash, boiler, firing, standpipes, summer, steaming, sun/shine, muggy, oasis, blazing.

Snow words: snow/s/y/ing, freezing, frozen, winter, icicle/s, ice/s/d, cold, biting, bleak, midwinter, blizzard/s, whiteout, snowflake/s, slush, snowstorm/s, frost/s/y/ed.

Wind words: wind/y/s, breeze/y, howling, gale/s, blustery.

Rain words: rain/y, umbrella/s, drop/s, droplet/s, drip/s/ped/ping, slosh, gargle, drizzle/s, mud/dy, gutter, piss, damp.

Temperate words: cool, temperate, warm, dewy, spring, sun, sunshine, warmth, mild, chilly, autumn.

Cloud words: cloud/s/y, mist/s/y, fog/gy, whiteness.

\section{References}

Barthes, Roland. 1987. The Rustle of Language. Translated by Richard Howard. New York: Macmillan.

Baucom, Ian. 2015. 'Moving Centers': Climate Change, Critical Method, and the Historical Novel. Modern Language Quarterly 76: 137-57. [CrossRef]

Best, Stephen, and Sharon Marcus. 2009. Surface Reading: An Introduction. Representations 108: 1-21. [CrossRef]

Biello, David. 2010. The New Normal?: Average Global Temperatures Continue to Rise. Scientific American. Available online: https:/ / www.scientificamerican.com/article/average-global-temperature-rise-createsnew-normal/ (accessed on 17 August 2017).

Buell, Frederick. 2014. Global Warming as Literary Narrative. Philological Quarterly 93: 261.

Chakrabarty, Dipesh. 2009. The Climate of History: Four Theses. Critical Inquiry 35: 197-222. [CrossRef]

Ghosh, Amitav. 2016. The Great Derangement: Climate Change and the Unthinkable. Chicago: University of Chicago Press. Harris, Paul A. 2015a. David Mitchell's Fractal Imagination: The Bone Clocks. SubStance 44: 148-53. [CrossRef]

Harris, Paul A. 2015b. Introduction: David Mitchell in the Labyrinth of Time. SubStance 44: 3-7. [CrossRef] 
McCarty, W. 2005. Humanities Computing. London: Palgrave Macmillan UK.

Meeks, Wayne A. 2000. Apocalyptic Discourse and Strategies of Goodness. The Journal of Religion 80: 461-75. [CrossRef]

Metz, Joseph. 2017. Genre beside Itself: David Mitchell's The Bone Clocks, Pulp Intrusions, and the Cosmic Historians' War. Critique: Studies in Contemporary Fiction 58: 121-28. [CrossRef]

Mitchell, David. 2007. Ghostwritten. New York: Knopf Doubleday Publishing Group.

Mitchell, David. 2014. The Bone Clocks. London: Sceptre.

Ng, Lynda. 2015. Cannibalism, Colonialism and Apocalypse in Mitchell's Global Future. SubStance 44: 107-22. [CrossRef]

Nixon, Rob. 2011. Slow Violence and the Environmentalism of the Poor. Cambridge: Harvard University Press.

Shoop, Casey, and Dermot Ryan. 2015. 'Gravid with the Ancient Future': Cloud Atlas and the Politics of Big History. SubStance 44: 92-106. [CrossRef]

Song, Min Hyoung. 2011. Becoming Planetary. American Literary History 23: 555-73. [CrossRef]

Suvin, Darko. 1972. On the Poetics of the Science Fiction Genre. College English 34: 372-82. [CrossRef]

Taylor, Jesse Oak. 2013. The Novel as a Climate Model: Realism and the Greenhouse Effect in Bleak House. Novel 46: 1-25. [CrossRef]

(C) 2018 by the author. Licensee MDPI, Basel, Switzerland. This article is an open access article distributed under the terms and conditions of the Creative Commons Attribution (CC BY) license (http:/ / creativecommons.org/licenses/by/4.0/). 